\title{
Influence of Situation on Calabar Sea Port's Utilization and Potentials for Cassava (Manihot Species) Produce Export to Asia
}

\author{
OluyemiAyorinde Akintoye ${ }^{1}$, Tokunbo Olorundami ${ }^{1}$,Samuel Uka Ukata ${ }^{1}$, \\ Charles Nkpena Ojong ${ }^{2}$, Joseph ErimEkeh ${ }^{2}$, Ubong Edet Harrison ${ }^{1}$ \\ ${ }^{I}$ Department of Geography and Environmental Science ${ }^{l}$, University of Calabar, Nigeria \\ ${ }^{2}$ Department of Research and Planning ${ }^{2}$ Cross River State Tourism Bureau Calabar-Nigeria
}

\begin{abstract}
Adopting the influence of situation approach, this study aims to unravel the reasons, why despite the large amount of funds expended by the Federal Government of Nigeria on the construction and provision of relatively modern facilities, the Calabar Sea Port has remained grossly underutilized. The analyses were very revealing, For instance the calabar port is located along a river, and is in fact a River Port. Thus there is the dire need for frequent dredging of the channel, and the use of pilot boats. Calabar Sea Port utilization is influenced by multidimensional factors, which sometimes can't be adequately controlledby port management. The negative situations of the calabar seaport also include its non-linkage to North Eastern Nigeria, by railway, a benefit enjoyed by Portharcourt and Lagos Sea portsas regards their own hinterlands ; the poor connectivity of Calabar, to the Aba-Ikot Ekpene-Calabar road Minking Aba, Onitsha, Uyo, Asaba and Benin industrial areas) and the Ikom-Calabar road (linking the North-Eastern Nigeria area).Overhead metal barricades at the Ikom bridge hinders the movement of very high vehicles; the immediate hinterland of the port is also characterized by the lowest level of industrial activities, as well as some of the least paid civil servants in the country, resulting in low consumption levels, in the distant hinterland area of North Eastern Nigeria, there are deep rooted religious and political imbroglios, the outcome of which are low productivity and large scale emigration; the Calabar Free Trade Zone (CFTZ) and Export Processing Zone (CEPZ)presently lack significant trickle-down effects for regional economic prosperity; port piracy and encroachment by Portharcourt and surprisingly Lagos Sea Ports, have resulted in loss of patronage, even from South-eastern areas of Nigeria, and to an extent from Akwa Ibom state, invariably due to poor road connectivity and more rigorous scrutiny of imports. Along the Nigerian coastline, Calabar is not a thoroughfare to any English speaking country, or nation, with which Nigeria does much international trade. The suggested designation of Calabar sea port for large scale agricultural produce export, including, Cassava chips and pellets, will separate it from the neck-breaking competitions, with other Nigerian sea ports. It is expected to culminate, in the improvement of the level of sea port utilization and regional employment situations, while assisting in the diversification of national economy
\end{abstract}

Keyword: Influence of Situation, Port Utilization,Cassava Chips and Pellets, Agricultural Produce

\section{Introduction}

As early as the last decade the Nigeria ports Plc has had seven sea ports, including the Calabar sea Port , which the federal military government of Nigeria, at that time designated as an autonomous transshipment port for Nigeria, with complementary functions to the then proposed Calabar Export Processing Zone (Nigeria Port Authority (1992). Since the Calabar sea port was completed in September 1978, it is arguably one of the most modern of Nigerian Sea Ports. However, its annual capacity of utilizationofl.5million metric tons, has for decades been grossly underutilized.

For instance, during the 1975/76 period, the level of utilization was 13.95 percent of installed capacity, and by 1980/81 the level of utilization has fallen to 10.8 percent. Further on in 1993 the situation remained gloomy, with total through-put being 236,934 metric tonnes, while in 1994 the total traffic flow fell to 176,000 metric tonnes. These levels of utilization considerably remained insignificant fractions of the 1.5 million metric tonnes per annum capacity. The Calabar Sea port being among the sea ports most affected by underutilization problems in Nigeria has invariably continued to experience the loss of vital revenue and custom duties, which may accrue to the federal government of Nigeria. There also are the resultant low fiscal returns on invested public funds in ports development and maintenance. These have great consequences on the socio-economic development of Cross River state in particular and Nigeria in general. This also signifies that there exists a necessity for a crucial enquiry into the various factors and events, which have resulted in this annual, and even decades long levels of underutilization.

In the present decade, there has been strong indications that efforts are being made at enhancing sea port development and efficiency in Nigeria, since maritimeand railway transportation, is now more than before 
being noted by the different tiers of government as vital parts of the commodity production and distribution processes(Johnson, 2011; Awosanya,2012; Naira Land, 2013; Nigeria News , 2013;Osagie., 2013).

Past studies of sea ports, too many to list, have considered the sea ports in isolation, while others focused largely on the facilities, channels and hinterlands of the ports. However, Baransky (1981) has emphasized the importance of studying, for instance, the situation of a country (and invariably a sea port), not in isolation, but in relation to transportation, market, trades, cultural centres and industrial areas. He defined situation as the relationship of a given point or territorial sector to some neighboring phenomena, which may have economic importance, in relation to conditions, which are created by man's activities in the course of historical processes. A study by Actia Consulting (2012) engaged in an assessment of the influence of the Gdańsk and Gdynia Sea Ports on the social and economic situation in the Pomorskie Region. Also Money (1973) suggested that a good study of maritime transportation should be concerned about sea ports; the ware houses, facilities, the terminus of the major route ways, installations, the land and inland transportation network,which converge on it. All such aspects are embraced by the concept of Situation (or relative location) and is accordingly adopted for the purpose of this assessment.

Thus, in this analysis, the calabar sea port (which in true sense, is in fact a "River port", would not be assessed in isolation, but in relation to other external factors, which could influence its level of utilization . Consequently, the objectives of the study include the identification of factors which has influenced the level of utilization of the Calabar sea port ; the examination of the patterns and trends of Sea Port developmentin Nigeria, and possible implications for Calabar Sea Port ; the examination of the possibility of the existence of hinterland competition between the Calabar sea port and other Nigerian sea Ports: and the proffering of solutions and recommendations, to identified problems from the analysis .

\section{The Significance of Nigerian Sea Ports Structural Changes}

Most of the non-crude oil included sea ports of Nigeria are important centers for the traffic in numerous types and forms of raw material and manufactured goods, which alters from time to time. Ogundana (1970) noted that sea ports are dynamic phenomena. Such dynamisms occur in the nature of function and status and could be absolute or relative in nature. A sea port is not an isolated distinct phenomenon, since it is inter related with other sea ports, most importantly those in the considerable neighborhood. Related sea ports could be classified or grouped into a port complex. These can be studied for level of dependency in the functional and infrastructural pattern.

According to Ogundana (1970) the period of 1910-1950 was characterized by port concentration. Since 1950 there has been a significant level of ports diffusion with reduction and increases respectively in port population during this era (Table 1).

In the colonial era (of sea port concentration) especially in 1950, only seven sea ports were in existence in Nigeria, while in 1910 there were fourteen (14) sea ports. Between 1910 and 1950 the sea ports at Ikang, Bonny, Akassa, Koko, Forcado, Opobo and Brass emerged. With the emergence of Lagos sea port as the prime port of Nigeria, the Port Harcourt sea port established in 1912 was ranked as the second in importance, even as early as 1922. The third position in this ranking was taken by Sapele sea port. While the sea ports of Calabar, and Burutu which were initially next (respectively) in ranking were already diminishing in importance (Ogundana, 1970).

In 1986 the cargo throughout (exclusive of crude oil) shows a decline in the traffic to $12,276,579$ tonnes, indicating a decrease of $4,127,109$ tonnes or $25.51 \%$, when compared to the figure in 1985 . Sea ports in Lagos were responsible for $61.6 \%$ of the total throughout, trailed by the River zone, which was responsible for 23.86 percent , Delta Port with 12.61\% and Calabar port contributed a meager $\mathbf{2 \%}$ (Nigeria Port Authority, 32nd Annual Report for the Year Ended, 31st December, 1986).

Table 1: The Pattern of Sea Port Evolution in Nigeria

\begin{tabular}{|c|c|c|c|c|}
\hline Phase & Time Period & Composite Form & Leading Port & Overall Trend \\
\hline I & $1500-1670$ & Initial Concentration & Gwata, Bonny Old, Warri & \multirow{3}{*}{$\begin{array}{l}\text { Unutilized port } \\
\text { Structure }\end{array}$} \\
\hline II & $1670-1750$ & Diffusion & $\begin{array}{l}\text { Old Calabar, New Calabar } \\
\text { Bonny, Brass }\end{array}$ & \\
\hline III & $1750-1860$ & Concentration & Bonny, Lagos & \\
\hline IV & $1860-1910$ & Diffusion & Lagos, Akassa, Calabar, Warri and Degema & \multirow{3}{*}{$\begin{array}{l}\text { Consolidation } \\
\text { with } \\
\text { Lagos as point of } \\
\text { sustained port } \\
\text { dominance }\end{array}$} \\
\hline $\mathrm{V}$ & $1910-1950$ & Concentration & Lagos and Port Harcourt & \\
\hline VI & $1950-1962$ & Diffusion & All Nigerian Ports & \\
\hline
\end{tabular}

Source: Hoyle and Hillings (1970) 


\section{Description of Calabar Sea Port and its Environs}

The Calabar Sea Port is located in Calabar. Calabar is the Capital city of Cross River state of Nigeria. It is located on longitude $08^{\mathbf{O}} 19$ 1' ' East and latitude $04^{\mathbf{0}} 59^{\prime}, 11^{\prime \prime}$, North. It is situated on a peninsular between the Calabar River and the Great Kwa River. Calabar is separated from the neighboring highland areas (eastward) by the rivers and broad expanses of low, wet and humid swampland. To the South of Calabar is the estuary of the Cross River, which empties its water into the Bight of Bonny.

The new Calabar sea port lies on longitude $8^{\mathrm{O}} 15$ " 20 East and latitude $04^{\mathrm{O}} 55^{\prime} 0$ " North, and about 93 kilometers from the main channel of the Cross River. The sea port covers an area of about thirty-eight (38) hectares of land: and has a fully buoyed river channel, which is about eighty(80) nautical kilometers long and one hundred and fifty (150) meters wide.( Aye,1967 and NPA, 1993).Consequently, Calabar Sea Port is in fact a "River Port", requiring frequent dredging of the channel to accommodate, bigger ships, and most often require pilot boats, for navigation .

\subsection{Climate}

Calabar and its environs come under the influence of equatorial climate, having uniformly high rainfall , temperature and humidity throughout the year. Calabar experiences annual rainfalls of over 3000mm with most of the rains coming between November and April and another period between May and October, with lesser rains. The highest (Maximum temperature is obtained between February and March $\left(31.4^{0}\right.$ $\mathrm{C})$ and in July $\left(23.1^{0} \mathrm{C}\right)$. Although temperature rarely rise above $32^{\circ} \mathrm{C}$, humidity ranges between $75-95$ percent (TESCO-KOZIT Consulting Engineers (Nig.) Ltd, 1972, Akintoye, 1995).

Consequently, there are two major seasons, the Dry Season lasting from November to March and the Rainy Season lasting from April to October The strongest winds occur during the Rainy Season, while the weaker winds characterize the Dry Season (TESCO-KOZIT Consulting Engineers (Nig.) Ltd, 1972 and Akintoye ,1995).. However slight climatic deviations, have been noticed in recent times.

\subsection{Tides and Waves}

The sea swell trend changes slightly throughout the year along the coastal areas of Calabar. The least swells are noticeable in the Dry season, while the Wet season is denoted by the prevailing high sea swell. The height of sea swells range from 304.8 to $914.4 \mathrm{~mm}$ in Dry season, while in the Rainy season, the swell range between 1219.2 to $1828 \mathrm{~mm}$ high. The average period of swell is estimated at 12 seconds for the "High Types", while the Shortest Types have an average interval of 5 seconds. The tidal range is 1.500 metres and the high water range is about 3.046 meters. The low water is also usually about 1.488 meters (TESCO-KOZIT Consulting Engineers (Nig.) Ltd, 1972, However with the influence of climate change more alterations of these patterns are not uncommon.

\section{The HistoricalTrends and Relative Position of Calabar Sea Port}

The position of the Calabar Sea Port near the estuary of the Cross River makes it one of the sea ports of the Gulf of Guinea and directly of the Bight of Bonny. The estuary of Calabar River provides easy access into the Bight of Bonny. This natural waterway, especially encouraged yearly trade with Europeans, since the Calabar River is known for its calm waters around Duke Town and Diamond Hill (University of Calabar, Undated).

Aye (1967) corroborated these, when he stated that "Old Calabar" has since its foundation earned its growth and livelihood by the sea, and it was the sea that made it once commercially famous on the west coast of Africa. He also noted that the calm water around Duke Town and Old Diamond Hill, had provided a considerably conducive and vital environment for international trade, between Europeans, especially the Portuguese merchants and sailors, as early as the fifteenth century.

Aye (1967) also pointed out, that before the middle of the twentieth century Calabar served the Southern Cameroun, as a vital exporting port terminal, for its agricultural produce, but this ceased drastically, when South Cameroun was politically merged, with Cameroun in 1961. This immediately reduced the commercial importance of the Calabar Sea port, since lesser quantities of produce became available, for export through the port. But he reject the suggestion, that the decline of Calabar (and invariably its sea port) was due to its isolation. He argued that, it was the same "geographical position" with its oversea gateway, which once made it commercially important. He consolidated this view by stating that wherever commerce exist, even in isolated areas it inevitably stimulates other subsidiary industries, the most leading of which is transportation.

Even Udo (1970) pointed out that the location of Calabar (and invariably its sea port) was also vital factor in the prosperity of Calabar in the early days of the trade in Palm Oil. He noted the role of Calabar as the leading educational centre for what was then Eastern States of Nigeria and for the period between 19011906, when Calabar was the political capital of British Protectorate of Southern Nigeria. 
But interestingly Udo (1970) went on to suggest that the political and economic importance of Calabar was affected since the second decade of the 20th century when the political and economic significance of its location was reduced. He attributed the change, among other things to the opening of roads and Rail ways which has resulted in the reduction in the use of waterways, and thus a sea port like that of Calabar, with no direct road or railway link to the main hinterland of the Eastern part of Nigeria, has suffered lose of vital trade. In his view, the sitting and development of the Port Harcourt Sea Port is the "most decisive factor" in bringing about the loss of trade and subsistence, at the Calabar sea port (and the fall in the level of its utilization).

According to Aye (1967) another situation arose in the year 1960, during which harsh economic conditions made it imperative for British and other foreign firms in Calabar to go out of business.( A transect walk carried out along Old Marina Road, in Calabar Old Harbour area, by these authors ,in October 2013 revealed several dilapidated warehouses and abandoned office buildings, with the names of renown European International Trading Companies). This was the beginning of the economic depression of Calabar, which between 1883 and 1906 was the headquarters of the Oil River Protectorate .That Old Calabar has declined is undeniable, compared to its status about four decades ago is thus a well established fact .

Udo (1970), agrees that since the second decade of the $21^{\text {st }}$ century, Calabar become a stranded depressed area (an area which has become depressed as a consequence of the failure of locational advantages. He argued that this is not different from the situation in similarly stranded areas, which are notably characterized by severe unemployment, resulting in the reduction of total income, enforced migration, reduction of buying power and other social problems.

\section{Contemporary Trends and Relative Position of Calabar Sea Port}

Data provided by Jaja (2011) shows level of sea port competition from 1996 to 2005 in Nigeria. Crude oil and LNG were the most important exports, while imports were largely manufactured goods. The report shows that Calabar Sea Port had the highest level of incomplete data entry for Annual Average Turn- around Time of Ships Completed at Nigerian ports (Days by ships). This may suggest that another problem of the port, could be inadequate data collection and dissemination, which may affect planning and management. It was revealed that, Apapa port's handling of dry cargo totals 50.8 percent, Port Harcourt (21 percent), and Tin Can Island (21.9 percent). In liquid cargo handling Okrika port (57 percent), Apapa (11.8 percent) and Federal Light Port ( 8.2 percent) were prominent respectively in liquid cargo handling. Strange enough, no reference was made to showcase the relevance of Calabar Sea Port in this aspect of data analysis.

Certain new developments and trends have significantly influenced the level of utilization of the calabar Sea Port, and may require the need for re-designation. The Lagos and Port Harcourt Sea Ports have been for decades, and may continued to be threats to the level of utilization of Calabar Sea Port. These two sea ports appear to be characterized by certain situations, which is not the case with the Calabar Sea Port.

For instance, Lagos (with the Lagos sea ports) is the focus and converging point of sea routes linking North South and South America, Asia (especially, Japan) and Europe, Lagos also possess the Murtala Mohammed International Airport, with air routes, also connected to almost all the major African, Asian, European and American cities, while its inland water route can be navigated, uptill Sapele also in Nigeria.

Locally, the Lagos Sea Ports are comparably linked up by road and railway to very important towns, cities and industrial centres as Lagos, Ibadan, IIorin, Benin City, the "Lagos-Ibadan,-IIorin, Industrial Zone", the "Benin -Sapele -Warri Industrial Zone" and the Kaduna-Kano-Jos Industrial Zone. These zones have a large concentration of food, timber, construction, engineering, motor assembly, printing, brewing, plastic fruit canning, cigarette, and chemical industries (Oboli, 1978).. Such connectivities, directly and/or indirectly influences the level of Lagos Sea port utilization.

The Port Harcourt sea port is also linked by road and rail line to the "Port Harcourt-Enugu-Onitsha Industrial Estate, which is made up of Aba, Umuahia, Enugu, Nkalagu, Onitsha and Warri.

The Calabar Air Port operates mainly local and few intercontinental flights. Also its sea port is linked by road and water ways to places with rural agricultural activities such as Taraba, Yobe, Benue, Bauchi, Plateau and Adamawa, which are relatively agrarian economies. Cities and towns such as Aba, Onitsha, Enugu and Owerri to which the Calabar sea port is linked by road are also being competed for by the Port Harcourt sea port ,which is advantageously linked to the National Railway Network (for wider subsistence). Although Lagos, Port Harcourt and Calabar sea port are linked by pipelines to evacuate crude and refined petroleum product, the denial of a linkage to the National Railway Network, the resultant non-linkage of Calabar Sea Port to the West -East Vertical Railway Line (WEVRL) and poor road connectivity have resulted in crippling levels of deprivation, in the area of cargo haulage and transport costs consideration for Calabar sea port.

Table 2, shows that the Calabar sea port has considerable shorter distance advantage by road to Makurdi, Jos, Yola, Bauchi, Maiduguri, and Damaturu, over Lagos (and invariably Port Harcourt sea port on some instances). However, such advantages are undermined by the increasing low level of agricultural and 
other extractive activities in these settlements. Also the free movement of very high goods conveying Trucks/Trailers, along this vital highway is hindered at the Ikom bridge, which has overhead metal barricades.

Table 2 :Camparative Distance (Kilometres)

\begin{tabular}{|l|l|l|l|}
\hline S/N & From State Capital & To Calabar & To Lagos \\
\hline 1 & Markurdi & 534 & 887 \\
\hline 2 & Jos & 872 & 1082 \\
\hline 3 & Yola & 1134 & 1442 \\
\hline 4 & Bauchi & 1004 & 1213 \\
\hline 5 & Maiduguri & 1467 & 1677 \\
\hline 6 & Damaturu & 1320 & 11553 \\
\hline 7 & Jalingo & 688 & 1446 \\
\hline
\end{tabular}

Source : Nigeria Ports Authority (1995)

Even in the year 2013, the situation of Calabar Sea Port has not changed significantly. The location of the Calabar Sea Port on the local and international sea routes has not improved, its fortune also. Notably, Calabar sea port still has no direct relevance to the North Atlantic sea route, which is one of the busiest and connects most of the world largest sea ports

\section{The Level of Economic Activities in the Hinterland of Calabar Sea Port}

The economic base of Calabar sea port includes all those agricultural and industrial or service activities, which generate or attract incomes in the hinterland of the sea port. Oboli (1978) pointed out that the hinterland of Calabar sea port can be divided into two major parts i.e. South Eastern and North Eastern Nigeria. The cash crops largely cultivated in the former area,decades ago include oil palm trees and rubber, while timber was equally abundant. In the North Eastern part of the hinterland of Calabar Sea Port Groundnut, Bennissed and cotton were largely cultivated.

Grain and root crop production in the then North Eastern Nigeria is presently not of significant importance to foreign trade or the utilization of the Calabar sea port. The fishing activities along the coastal areas of Akwa Ibom and Cross River States are not presently economically of export trade level. The inadequately policed coastlines of the Nigerian nation, are usually the poaching grounds for international fishing trawlers. The fishing activities in the hinterland water bodies and especially the River Niger and Benue are almost subsistence in nature.

Notably, the patronage of the sea port of Calabar was initially based on slave trade. Oil palm and palm kernel, became dominant with the abolition of slave trade. Around the time of colonial administration the wide areas of the sparsely inhabited countryside offered great opportunities for plantation agriculture, timber exploitation and European and government owned farming estates in the law lying region called the Cross River Plain or basin (Udo, 1970).Except for the Adamawa area, the hinterland of Calabar Sea port is no longer important for cattle rearing. However, some parts of Bornu, Bauchi, Adamawa, Benue and Taraba have significant importance as sheep rearing areas. Figures1 and 2, show major crop producing areas, as well as industries and centres of production in Nigeria . In particular, Figure 1, showcase the domestic and international trade routes, along with Cotton, Oil palm, Cocoa and Groundnut producing areas. Note the low level of activities within the Calabar sea port hinterland, and the lack of railway connectivity. It is a fact in the present decade, that major cash crops, such as Cotton and Groundnut are no longer densely cultivated, Cocoa is not economically cultivated within Calabar Port hinterland, except in areas like Ikom, in Cross River state, while Oil Palm cultivation is restricted to the South Eastern areas of the hinterland. Even most of the Oil Palm plantations, in private and especially those in government plantations, are senile and have passed the optimum production ages.

Also the major routes for exports by rail, river and road are mainly focused on Lagos and Port Harcourt Sea Ports, while Calabar Sea Port is significantly deprived of such valuable subsistence. Such mineral resources as Tin and Colombite at Jos Plateau and Coal at Enugu exists, and were mined in the past in commercial quantities. Other valuable minerals include zinc and Tungsten. These were exported mainly through both the Port Harcourt and Lagos Sea Ports at the detriment of the Calabar sea port.

For a very long time, Akwa Ibom and Cross River States have been among the elite crude oil producing states in Nigeria. This advantageously, has contributed to the increase in the level of utilization of the oil bunkering facilities at Quo Iboe, Eket and Atan terminals (Abasiattai, 1987). Only recently was Cross River state made to give up several oil wells, a situation which has further compounded the economic problems of Cross River State, which is a major and immediate hinterland of the Calabar Sea Port.

In the hinterland of Calabar sea port, the population of large scale and small scale industries is sparse. The Benin-Sapele-warri zone, Kano-Kaduna-Jos Zone and Lagos-Ibadan-IIorin Zone are not located in the Calabar sea port hinterland (Oboli, 1978). While there is a dense concentration of market oriented industries in 
Lagos, Ibadan, warri, Benin City, Kano, Kaduna, and Port Harcourt which are areas served by both the Lagos and Port Harcourt sea ports, the industrial towns and cities of Aba, Onitsha, Owerri and Enugu are served competitively by both Port Harcourt and Lagos sea ports and in some few cases by Calabar sea ports.

Figure 1

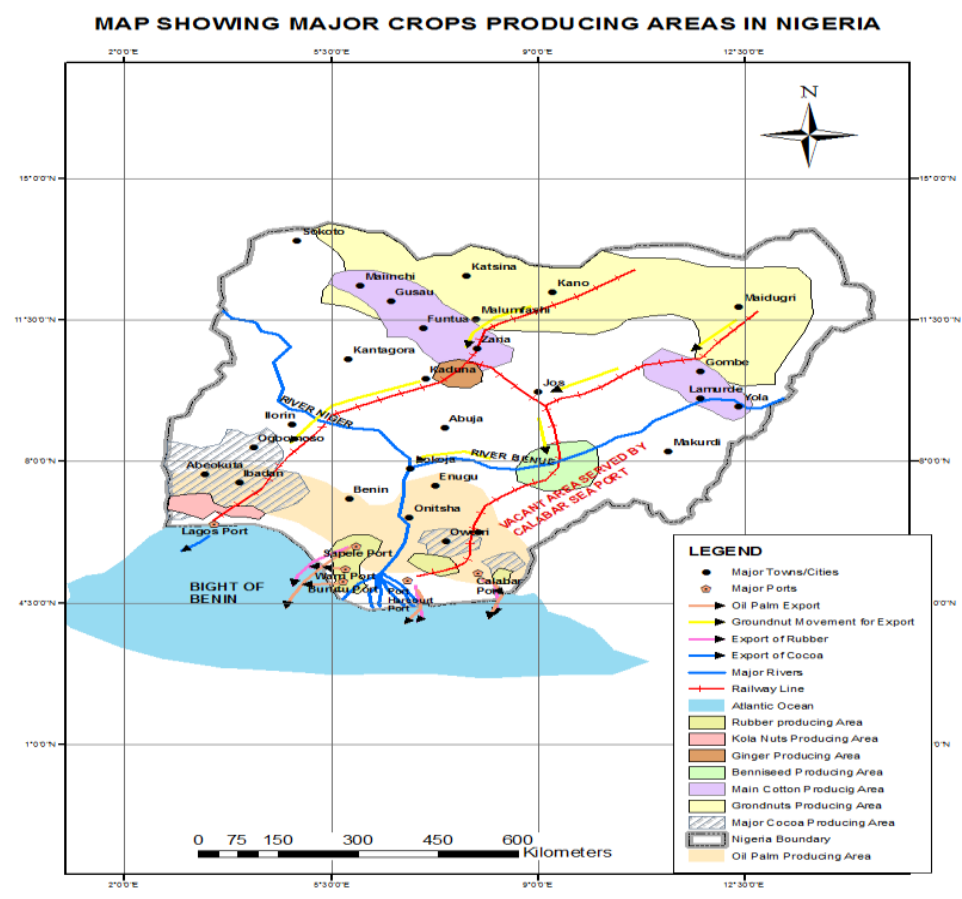

Figure 2

MAP SHOWING INDUSTRY AND CENTRES OF PRODUCTION IN NIGERIA

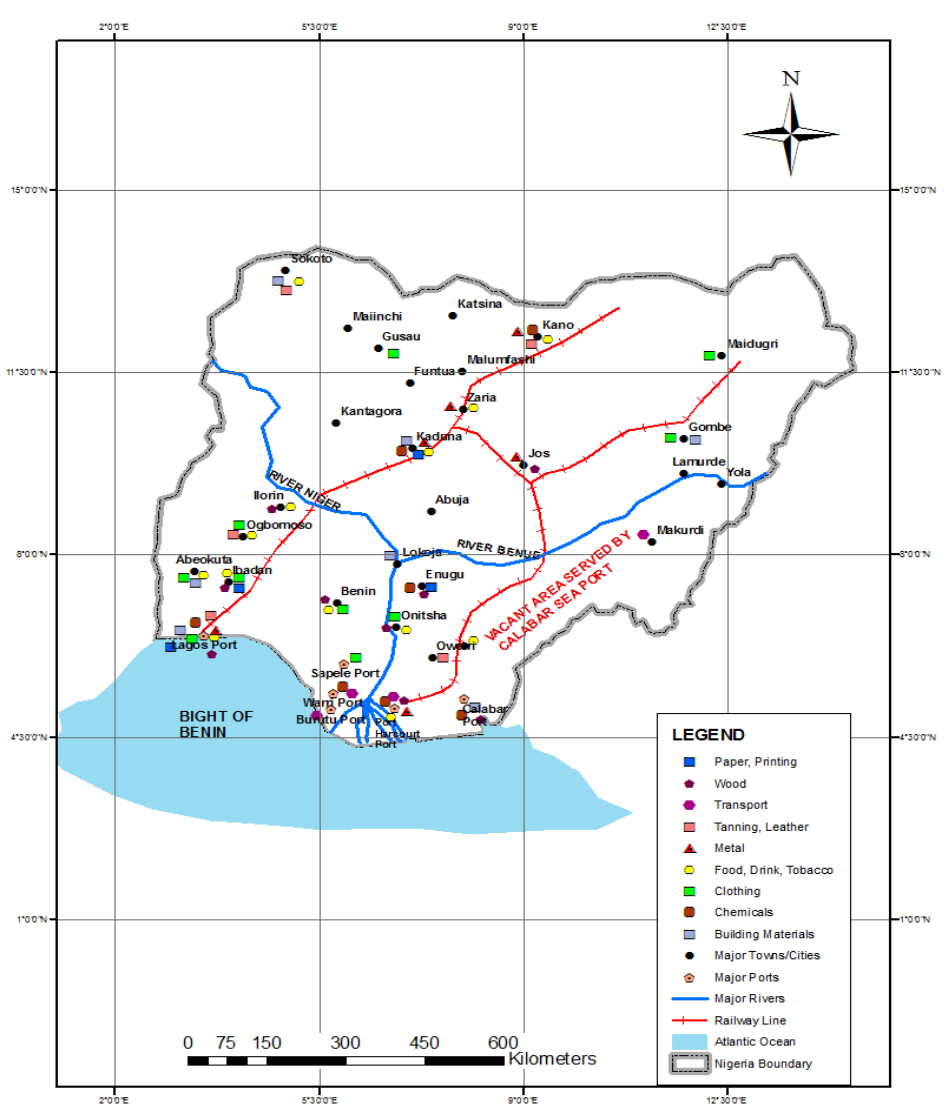


Comparatively, in the Lagos Sea Ports' immediate hinterland area ,are industrial estates at Apapa , Ijora, Yaba, Oshodi, Agbara, IIupeju and Ikeja, while Port Harcourt sea port has the trans-Amadi and Port Harcourt Industrial estates. These two sea ports are also well linked through road and Rail transportation to the industrial estates in Kano, Kaduna, Jos and Zaria. Such activities tend to boost inward and outward movement of raw materials, spare parts and the exportation or importation of finished or semi finished industrial products. Since the Calabar sea ports hinterland is significantly denied of such subsistence and its area of subsistence limited by the non-linkage to the national railway and poor road network, its level of utilization is reduced.

Considering the distance decay factor, the Calabar Sea Port depended highly for several years on such industries within Calabar and its environs, especially along the Highway axis, including CALCEMCO (Calabar Cement Company), Seromwood, Flour Mill Ltd., Quality Ceramic Ltd., Paint Factory, Biscuit Factory, Sunshine Battery, Cross River Breweries, Eastern Match industry (Ndem, 1991,15-16). Notably all these industries except about two have folded up .Only the cement industry (taken over by Dangote Investment) and Flour Mills Industries, are presently operating .A study by Akpogome (1982) is also revealing, and highlights the situation of Calabar Sea Port from the last two decades.

\section{Realities of Challenges Facing Calabar Sea Port Utilization in Recent Times}

The recent loss of numerous crude oil wells by Cross River state and seceding of Bakassi peninsula to Cameroun, have both had crippling effects, on the socio-economic well being of Cross River state. These invariably, have affected government and household income and as well as consumption patterns, which would have necessitated the use of a sea port. A sea port is an interface for the inward and outward movement of passengers and goods.

The Calabar Export Processing Zone (CEPZ) and TINAPA Business Resort, were meant to be the panaceas, meant for the rapid improvement of the Calabar Sea port. The reality is that only CEPZ shows a faint promise of fulfilling the intention(s) for its creation, with dozens of functioning local and multi-national industries, but compared to Export Processing Zone in Asia, there is much to be desired.

However, TINAPA business Resort needs better strategies for improvement of its own level of utilization, before it can be expected to have considerable impact on the utilization of Calabar Sea Port. Recently, TINAPA, which consumed about 350 Million US Dollars for development, has received new set of investments from Asset Management Corporation of Nigeria (AMCON), which is buying back TINAPA's debt totaling N18, 509, 774,797.05 and will provide the sum of N26 Billion for revitalization, resuscitation and repositioning of the resort a private sector driven initiative, along with a new shorter road-linkage, from Calabar to Adiabo Community (where the resort is located), being built by the Federal Government, the potentials can be limitless. .

So far, all these appears not to have altered the continued low level of Calabar Port utilization .Donatus (2012: 42) in presenting data on descriptive statistics of port metrics (Table 3 ) shows that Calabar Sea Port recorded a meager 203.643 thruput $^{1}(\mathrm{~m})$ compared to other ports, yet the labour (Net- gang- hour) input was relatively high, compared with the thruput to labour inputs for other sea ports.

Given the scenario painted above of the decade's long inadequate utilization of the Calabar sea port, and the failure of industrialization innovation, there is a dire need for more robust strategies to be formulated, aimed at solving identified problems. Among these strategies are the stimulation of local and regional trades within and outside the hinterland of Calabar sea port, improvement of transportation network and massive industrialization efforts. However, the potential of a diversification of the Nigerian Economy, cannot be over emphasized.

Table 3 : Descriptive Statistics of Port Metrics

\begin{tabular}{|l|l|l|l|l|l|}
\hline S/N & Ports & Throughput $^{\mathbf{1}}(\mathbf{m})$ & Berths & Equipment & Labour \\
\hline 1 & Apapa & $4,215.980$ & 22 & 188 & 18.348 \\
\hline 2 & Container Terminal & $2,071.280$ & 6 & 100 & 18.652 \\
\hline 3 & Tin Can Island & 2571.450 & 14 & 140 & 19.043 \\
\hline 4 & Ro- Ro & 604.799 & 3 & 70 & 17.391 \\
\hline 5 & Warri & 746.832 & 22 & 116 & 19.478 \\
\hline 6 & Portharcourt & $1,680.050$ & 8 & 104 & 19.174 \\
\hline 7 & Onne & $1,090.920$ & 5 & 8 & 19.174 \\
\hline 8 & Calabar & 203.643 & 14 & 74 & 17.783 \\
\hline
\end{tabular}

${ }^{1}$ Thruputs (000), * ngh: net gang hour: Nigerian Ports Authority

Source :Donatus (2012: 42)

The governments at different levels and Nigerians themselves, have for decades reiterated the need for the return of the national economy to the dependence on agriculture and exportation of farm produce, as demonstrated by the cocoa, palm oil and groundnut trades in the sixties and early seventies. Crude oil exploitation has resulted in large scaleand free for all indulgence in corruption, widespread environmental 
pollution and resource control agitations, associated with acrimony and mayhem. There is thus, the need to examine and exploit the myriads of potentials, offered by agricultural produce exports in particular.

\section{Need to Diversify the Nigerian Economy as a Strategy for Improving the Level of Utilization of the Nigerian Sea Ports}

Presently, over 80 percent of the Nigerian National Budget has depended on Crude oil sales, and recently inputs made by the construction and operation of the Nigeria Liquefied Natural Gas (NLNG) has been very massive, even in turbulent operational environment characterizing Liquefied Natural Gas (LNG) gas gathering, liquefaction processes, demand and sales. Arguably, petroleum resources exploitation has brought as much good as evil on the Nigerian economy. This is much so since the industry has been characterized by large scale crude oil spillage, oil bunkering, and clamor for resource control and capital flight.

All these have been at the expense of agriculture, manufacturing and the tourism industry. However the tourism industry has a very high correlation with increase in sexually transmitted diseases (STDs) and erosion of culture and values, while Nigeria lack the in-depth indigenous technical knowhow and regular supply of electricity power, necessary for sustained industrial productivity. These are the major issues with tourism and manufacturing as options to diversification of Nigerian economy.

The panacea, which agriculture and produce exportation, in Nigeria, a country with widespread diversities of fertile soils, an endowment (craved by even advanced countries like South Africa, China and Japan), offer is best imagined. This has been demonstrated in recent activities in the cassava chips export efforts by the federal government, in which railway and sea ports are meant to play important roles.

Already, there are arable and cash crops which are traded internationally, by Nigerians, ranging from Cacao, Ginger, Garlic, Rice, Sorghum, Cassava, Cow Peas and Soya Beans, amongst several other crops with export potentials. However, data by Nweke (1997) revealed that cassava has prominence in cropping pattern among other arable crops (Table 4).Potentials of cassava as a major raw material ,was comprehensively , reported by the Department of Agriculture, Federal Ministry of Agriculture and Natural Resources (1997) .It also highlighted an example of present industrial utilization of Cassava in Nigeria, when it indicated that

Table 4 : Percentage Distribution of Crop Fields by Cropping Pattern

\begin{tabular}{|c|c|c|c|c|c|c|}
\hline $\mathrm{S} / \mathrm{N}$ & Crop & Number of Fields & Sole & Major & Minor & Total \\
\hline 1 & Cassava & 494 & 36 & 38 & 26 & 100 \\
\hline 2 & Yam & 163 & 13 & 79 & 8 & 100 \\
\hline 3 & Maize & 306 & 9 & 13 & 78 & 100 \\
\hline 4 & Rice & 34 & 82 & 6 & 12 & 100 \\
\hline 5 & Sorghum/millet & 100 & 19 & 41 & 40 & 100 \\
\hline 6 & Beans/peas & 92 & 20 & 10 & 70 & 100 \\
\hline Total & All crops & 1189 & 25 & 35 & 41 & 100 \\
\hline
\end{tabular}

Source: Nweke et al (1997)

the Nigerian Yeast and Alcohol Manufacturing Company (NIYAMCO), uses about 24 tonnes of cassava chips daily in producing alcohol, while cassava is a very important staple food. But the comparism of the cost of production and current international market price, may not allow Nigeria to compete favorably in cassava chips exportation.

Its thus, not surprising, that there is a growing export trade in cassava, in Nigeria in recent times. For instance Osagie (2013) indicated that Nigeria is to export \$272m worth of Cassava Chips to China, while Naira Land (2013) itemized procedures for produce export from Nigeria(Figure 3) .Nigeria News (2013) reported that a former Nigeria Head of State ,Olusegun Obasanjo was involved in the exportation of "Cassava Bread" to Tanzania.

Awosanya (2012) also reported that, the Nigerian Railway Corporation (NRC) is partnering the Federal Ministry of Agriculture for haulage of cassava chips to the world. The first train of 160 tonnes of cassava chips has already been moved to Lagos Seaport from Ilorin, for later exportation to Asia. Henceforth, empty wagons would no longer return to Lagos as they would be hauling cassava chips from Ilorin to Lagos seaport. Cassava farmers and invariably exporters, were advised to use the opportunity for a competitive global trading.

Thus it appears that there is a new awareness and efforts to capitalize on Cassava crop for household and industrial uses. Here lies a major opportunity, for the increase of the utilization of Calabar seaport, if a significant volume of such export, especially those from the middle belt, Northern-Central and to an extent Southern areas of Cross river state, Akwa Ibom state and North Eastern Nigeria are directed to it. 


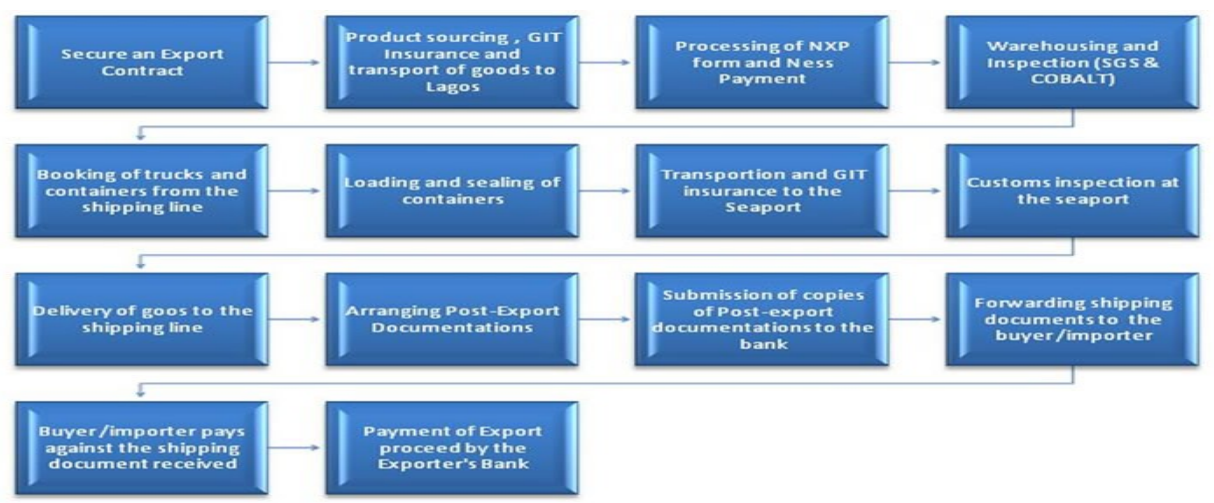

Source : Naira Land (2013)

Figure 3 : Procedures for Agricultural Produce Exports from Nigeria Chart

IX. The Prospects and Problems of Cassava Production in Nigeria for Export Purposes

Cassava is a crop that tend to do well in soils with low nutrient values, and its cultivation by developing countries in the tropics, found in such areas as Oceania, Africa, Asia and Latin America, and Oceania is well documented . Cassava is a crop requiring very low level of cultural operation , water input , fertilizer application . (Vessia , 2007 ; FAOSTAT, 2009 and FAO, 2009 in Tijaja ,(2009).

Jidere and Okere (2012) have highlighted the climatological characteristics of Nigeria, (Tables 5 and 6). The climatologically requirements for cassava cultivation is satisfied almost in all areas of Nigeria, except in extreme northern areas. While the Department of Agriculture, Federal Ministry of Agriculture and Natural Resources (1997) pointed out that the broad expanse of Nigeria's land spreads from latitude $4^{\circ} \mathrm{N}$ to $14^{\circ} \mathrm{N}$ and from longitude $3^{\circ} \mathrm{E}$ to $14^{\circ} \mathrm{E}$. Of this area, about 71 million ha ( 77 percent) are estimated to be suitable for cultivation. Around 32 million ha or 45 percent of the total cultivable land area, are used for cultivation purposes .Although there are disparities in pattern of precipitation in the country, with annual rainfall ranges from $2500 \mathrm{~mm}$ in the coastal areas to about $500 \mathrm{~mm}$ in the far north.

Table : 5 Agro-Ecological Zones in Nigeria

\begin{tabular}{|l|l|}
\hline $\mathbf{S} / \mathbf{N}$ & Description \\
\hline 1 & $\begin{array}{l}\text { The Sudan savanna agro-ecological zone (semi-desert Sahel savanna): Latitudes } 12^{\circ} 2^{\prime} \text { and } 13^{\circ} 8^{\prime} \mathrm{N} \text { and } \\
\text { longitudes } 3^{\circ} 9^{\prime} \text { and } 13^{\circ} 9^{\prime} \text { E. Low relative humidity }(40 \%) \text {. Annual rainfall }(65-100 \mathrm{~cm})\end{array}$ \\
\hline 2 & $\begin{array}{l}\text { The northern Guinea savanna agro-ecological zone: Latitudes } 9^{\circ} 4^{\prime} \text { and } 11^{\circ} 5^{\prime} \mathrm{N} \text { and longitudes } 3^{\circ} 8^{\prime} \text { and } \\
13^{\circ} 1^{\prime} \mathrm{E} \text {. Annual rainfall }(90-120 \mathrm{~cm}) .\end{array}$ \\
\hline 3 & $\begin{array}{l}\text { The mid-altitude plateau agro-ecological zone: Altitude of about } \\
1,300 \mathrm{~m} . \text { Latitudes } 4^{\circ} 6^{\prime} \text { and } 9^{\circ} 5^{\prime} \mathrm{N} \text { and longitudes } 8^{\circ} 5^{\prime} \text { and } 9^{\circ} 2^{\prime} \text { E. Annual rainfall }(140-143 \mathrm{~cm}) \\
\text { with temperature rang }\left(21^{\circ} \mathrm{C}-25^{\circ} \mathrm{C}\right) .\end{array}$ \\
\hline 4 & $\begin{array}{l}\text { The southern Guinea savanna (derived savanna) agro-ecological zone: } \\
\text { Latitudes } 7^{\circ} 4^{\prime} \text { and } 8^{\circ} 7^{\prime} \mathrm{N} \text { and longitudes } 4^{\circ} 1^{\prime} \text { and } 12^{\circ} 2^{\prime} \text { E. Annual rainfall }(100-150 \mathrm{~cm}) . \\
\text { Characterized by tall grasses and trees due to repeated burning of forest }\end{array}$ \\
\hline 5 & $\begin{array}{l}\text { The humid forest agro-ecological zone: } \\
\text { Latitudes } 6^{\circ} 4^{\prime} \text { and } 7^{\circ} 5^{\prime} \mathrm{N} \text { 'and longitudes } 3^{\circ} 5^{\prime} \text { and } 8^{\circ} 8^{\prime} \text { E. Annual rainfall }(130-150 \mathrm{~cm} \text { and } 200 \\
\\
\text { cm in some places). High relative rainfall }\left(80^{\circ} \%\right) .\end{array}$ \\
\hline
\end{tabular}

Source : Jidere and Okeke (2012) as classified by Iloeje (1981)

Table 6:Agro-ecological Zones of Nigeria with some Climatic Characteristics

\begin{tabular}{|l|l|l|l|l|l|l|}
\hline S/N & Zones description & \% of Land & Annual Rainfall (mm) & \multicolumn{3}{|l|}{ Monthly Temperature ${ }^{\mathbf{O}}$} \\
\cline { 4 - 7 } & & & & Maximum & Normal & Minimum \\
\hline 1 & Semi-Arid & 4 & $200-600$ & 40 & $33-32$ & 13 \\
\hline 2 & Dry Sub Humid & 27 & $600-1000$ & 49 & $31-21$ & 12 \\
\hline 3 & Sub Humid & 26 & $2000-1300$ & 37 & $30-23$ & 14 \\
\hline 4 & Humid & 21 & $1100-1500$ & 37 & $30-26$ & 18 \\
\hline 5 & Very Humid & 14 & $1120-2000$ & 37 & $28-24$ & 21 \\
\hline 6 & Ultra Humid (Flood) & 2 & $2000+$ & 33 & $28-25$ & 23 \\
\hline 7 & Mountainous & 4 & $1400-2000$ & 32 & $29-124-$ & 5 \\
\hline 8 & & & $1400-1500$ & 36 & 204 & $24-20$ \\
\hline
\end{tabular}

Source : Jidere and Okeke (2012) 
Broadly speaking, the cassava-growing belt falls within three agro-ecological zones of the southeast, southwest and the central areas. Nigeria is currently the largest producer of cassava in the world with an annual production of over 34 million tonnes of tuberous roots (Department of Agriculture, Federal Ministry of Agriculture and Natural Resources,1997)

Thus, it is expected that Cassava will do well in a wide expanse of areas within Nigeria, from the water logged Niger Delta areas, to the rich tropical soils of western Nigeria, the devotedly agrarian middle belt , South eastern Nigeria (characterized by large scale erosional activities), the South -South area of Nigeria and even farther North, where rainfall are least available.

Although all these potentials for massive production exists, for cassava production and export, issues which have militated against large scale production, processing, storage, transportation and marketing are numerous as highlighted by the International Institute of Tropical Agriculture (2005) and The Punch Newspaper (2013).

Interestingly, but not surprisingly, the International Institute of Tropical Agriculture (IITA) in collaboration with United States Agency for International Development (USAID),Nigeria Mission and Shell Petroleum Development Company (SPDC), Nigeria, have focused on efforts aimed at mitigating the impact of Cassava Mosaic Disease (CMD), while and preventing its spread throughout Nigeria and in other West Africa countries. This concern has underlined the potentials of Cassava.

Strategies discussed to achieve this by IITA include diversification, participatory evaluation, multiplication and distribution of CMD resistant germplasm to farmers; increase of cassava productivity by developmental researches, promotion of improved germplasm, soil amendments, integrated pest management options and others which include the encouragement of the development, as well as the expansion of postharvest processing and storage, including the identification of marketing outlets for cassava products, aimed at increasing household incomes of those involved in cassava production, processing and sales improvement aimed invariably at improving the livelihood of families and/or individuals in rural areas (IITA, 2005) .Department of Agriculture, Federal Ministry of Agriculture and Natural Resources (1997) emphasized the contributions of government, research institutes, women, private organizations, genetic improvement and other factors to cassava development. The ministry also outlined the course of future contributions.

The expected outcome and achievement of this collaborative efforts, according to the IITA (2005) include the reduction of the consequences of Cassava Mosaic Disease (CMD) on cassava production, through diversification, participatory evaluation, multiplication and distribution of CMD-resistant germplasm to farmers., enhance the volume of cassava harvests through the generation, promotion and adoption of demand driven, competitive and sustainable cassava production. Lastly, it is expected that post-harvest processing and storage, as well as improvement, through adequate development and purposeful expansion in marketing outlets for cassava products.

\section{Insight into the Production Pattern and Demand for Cassava Produce in Asia: The Thailand and China Scenarios}

Worldwide Cassava as a crop is known for its very high ability to thrive and do well with the least application of fertilization, low rainfall and cultural operations. It is a crop that that has great potentials for impoverished farmers, cultivating low nutrient soils. Since the root can be left in the soil for up to two years without considerable damage to its nutrient properties, its also a very valuable type of crop for food security. Quoting FAO (2009) ,Tijaja (2009) reported that of the around 242 million tonnes of cassavas produced in 2009 , not up to 21 percent was marketed globally .It is known that five countries, including Nigeria, Thailand, Brazil, Indonesia and Democratic Republic of Congo, are responsible for more than half of world production of cassava .

Of these, Nigeria produces 19 percent of world Cassava output, making it the highest producer in the year 2009. Following Nigeria, is Thailand which is the second largest producer responsible for 13 percent, which is a remarkable growth in production from a mere 3.5 percent in the year 1970 (Vessia, 2007, FAOSTAT, 13 November 2009, FAO, 2009 in Tijaja, 2009).Tijaja (2009) referring to Kaplinsky et al (2010) expressed dismay, over the observation that despite being only the second largest producer of Cassava, Thailand has strategically established itself as the leading exporter of Cassava in the world. As early as 2008, Thailand has earned $\$ 910$ million, for about 80 percent of global cassava. Though in 2009, Vietnam replaced Thailand in dried cassavas export importance .

The most important importer of Cassava worldwide has been China. Being both in Asia, China and Thailand are very close. This is not the case between China and Nigeria, which needs to transport its cassava produce, from the region of production with railway and later longer periods of shipping, for a highly perishable product in processed or non-processed forms. These may be constraints to the Nigerian trade with Asia, and invariably China. Table 1: presents the composition of Thailand's Cassava Exports to China from 2008 to 2002.Table 7, presents data on composition of Thailand's Cassava Exports to China. 
Tijaja(2009) pointed out that China's economic growth and industrialization has resulted in the rapid increase in the need for various types of commodities, required for its industrial activities. It is presently the highest importer of world output of many major agro commodities. China presently focuses largely at the less processed products such as chips from the dried cassava value chain, and native starch from the starch value chain. To the advantage of developing countries within the tropical areas, such less processed products, need considerably lower technology and sophisticated processing, and as such could be easily ventured into ,by developing countries in Africa, Latin America and Asia, and Oceania. The major focus of Chinese imports includes chips and Pellets. Pellets are made from chips and, as well as the waste from starch processing.

Table 7 : Composition of Thailand's Cassava Exports to China

\begin{tabular}{|l|l|l|l|l|l|l|l|}
\hline & $\mathbf{2 0 0 2}$ & $\mathbf{2 0 0 3}$ & $\mathbf{2 0 0 4}$ & $\mathbf{2 0 0 5}$ & $\mathbf{2 0 0 6}$ & $\mathbf{2 0 0 7}$ & $\mathbf{2 0 0 8}$ \\
\hline Total (\$m) & 109.02 & 137.44 & 236.74 & 329.87 & 474.81 & 417.62 & 288.30 \\
\hline Of which is (\%) & 94.10 & 94.66 & 90.04 & 89.44 & 87.61 & 83.26 & 72.57 \\
\hline Dried cassava & 9.96 & 9.96 & 10.56 & 12.39 & 16.74 & 27.43 \\
\hline Cassava starch & 5.90 & 5.34 &
\end{tabular}

Source: UNCOMTRADE inTijaja (2009)

Even before President Barrack Obama's present efforts, the previous governments of the United State of America and her scientists, have been poised on research activities aimed at producing alternatives to petroleum products. Hayes (1977:193) listed Cassava (Manioc) as an energy crop which has "their advocates among bioconversion specialists" . Hayes (1997) pointed out that "Brazil recently had embarked on a 500 million US Dollars programme to dilute all gasoline by 20 percent with ethanol made from sugar cane and cassava" .Ethanol which could very easily be obtained from Cassava could furnish Nigeria with another opportunity, to market its massive production of the produce. Thus, there is a dire need to consider other markets, worldwide.

What is left is for Nigeria to harness its resource, for the widespread cultivation of agricultural crops , for which it has great economic advantages, identify countries needing such produce, consider percentages required for internal household and industrial consumption, device means of processing and packaging, as well as transportation modalities, that could compete against even Thailand that is in the same continent as China and India. Efforts should be made not to depend largely on mono-cultivation. The consequences of a fall in world price, disease outbreak, change in technology requiring demand for introduction of another crop or synthetic material for production, and the outbreak of crop yield reducing disease(s).

In every socio-economic activity, such as a focus on agricultural productivity increase, there can be positive and/ornegative outcomes, and these should also be considered. Todaro and Smith (2004) have comprehensively discussed various issues on economic development, especially in developing countries. In the focus on Nigeria ( $p$ p 72- 77) recommendations for Nigerian development include need to "make greater use of market price initiatives to allocate resources, while endeavoring to improve public and private decision making “. An attempt to compare Nigeria with Bangladesh (another Asian Country, like China and Thailand) in a discussion of the neglect of agriculture in Nigeria (pp 503-507) revealed some socio-economic problems, even at household levels, which labour intensive agriculture may escalate.

The road to sustainable and rapid economic development for Nigeria as a whole should, thus be based on strategies aimed at realizing National Integrated Development, which is dependent on the development of all the (relevant) sectors together, with adequate knowledge of their direct and indirect interrelationships, where one sector enhances the others, and utilizes even emerging problems for the progress of other sectors. Consequently, improvement in the level of utilization of Calabar Sea port must be based on the outcome and proceeds from integrated measures aimed at widespread socio-economic improvement, which will culminate in high level of sea port utilization. One of such is the stimulation of agricultural produce cultivation, and designation of Calabar Sea Port for major roles in export activities in Nigeria. Conflicts in approach to development as distinguished by Gary (1980) in Todaro and Smith (2004) which distinguishes among three development typhologies ; (i) The Modern -sector Enlargement Growth Typology, (ii) The Modern-sector Enrichment Growth Typology and The Traditional-sector Enrichment Typology needs further examination.

\section{Summary}

The analysis traced the historical and developmental trends of the Calabar Sea Port. Area of focus include and examination of the possible existence of port piracy, socio-economic activities in the immediate and distance hinterland of the Calabar Sea Port, level of road connectivity and port linkages, need to diversify the Nigerian economy, the potentials of agricultural produce export, the designation of Calabar Sea Port as the major agriculture produce export interface, as well as the demand and supply mechanism in Asia. 
Problems which culminate in the low utilization of Calabar sea port are numerous, and include the relationship of the port with other sea ports, political significance over the decades, and need to frequently dredge the Calabar River, for ease of passage for bigger ships, since Calabar Sea Port is in fact a "River port".

Past efforts at industrialization (given the epileptic nationwide electricity power supply), aimed at Calabar Sea Port utilization improvement has been grossly unsuccessful. Present efforts at TINAPA and CEPZ management should however not be underrated. The way forward, include the resuscitation of Nigeria's agricultural productivity for export, and the designation of the Calabar Sea Port as a major shipment interface, to protect it from strong competition with other Nigerian sea ports with better facilities and situations. This is not an end in itself. The large scale production of Cassava with its potentials for cultivation almost all over Nigeria is here strongly recommended.

However the identified problems of sea port utilization in Nigeria, may also need muti-facetted approaches, characterized by the integrated development option. The level of utilization of a seaport is a reflection of the level of development and totality of the socio-economic activities, in its hinterland. As such , other developmental outlooks, are required. Choices of developmental approaches made, may requires more careful selection and adoption processes .

\section{Recommendations}

The recommendations proffered for this study include,

- the designation of Calabar Sea Port as a major if not sole interface for the outward shipment of agricultural produce , including, but not necessarily limited to Cassava chips and pellets;

- there should be increased effort to provide complete data on Calabar Sea activities port for international trade planning and information to present and potential port users ;

- updating of obsolete equipments to keep pace with a rapidly changing operational environment internationally;

- need for improvement in services provided by ship repair and equipment management crews, banks , immigration and security units, engaged in sea port activities ;

- need for removal of bureaucracy, introduction of sub-regional bilateral trade agreements, and involvement in transshipment activities to improve cargo and passengers transportation

- trade liberalization should be encouraged through government fiscal policies to quicken import and export documentation, pre-shipping inspection, reduce vandalization and stealing of ports users goods and improve road, inland waterways and railway connectivity

\section{Reference}

[1]. Abasiattai., B.M (1987) Akwa Ibom and Cross River State: The Land, the People and their Culture,Wusen Press Ltd. , Calabar.

[2]. Actia Consulting (2012)The assessment of Influence of Gdańsk and Gdynia Sea Ports on the Social and Economic Situation in the Pomorskie Region, http://digital.library.okstate.edu/oas/ oas pdf/v38/p128 131.pdf (Accessed : 21-9-2013)

[3]. Akintoye O.A (1995) The Influence of Situation on the Utilization of the Calabar Sea Port, A Bachelor of Science Degree Thesis, Department of Geography and Regional Planning, University of Calabar, Calabar, Nigeria

[4]. Akpogome, OS (1982) The Impact of Calabar Sea Port on its Hinterland : 1975-1981, Bachelor of Science Degree Thesis , Department of Geography and regional Planning, University of Calabar, Nigeria

[5]. Awosanya .,Y (2012).Nigerian Railway partners Agric Ministry for cassava exportation,Naija AgroNet , Friday, August 10, 2012 , http://www.naijaagronet.com.ng/2012/08/nigerian-railway-partners-agric.html( Browsed: 20-1-2013)

[6]. Aye .,E (1967) Old Calabar Through the Centuries, Hope Waddel Press, Calabar

[7]. Baransky, N (1981) Selected Works in Geography, Progress Publishers, Moscow

[8]. Cole .J.P., (1979) Situations in Geography, A Practical Approach, Basil Blackwell Oxford, London

[9]. Department of Agriculture Federal Ministry of Agriculture and Natural Resources (1997) Cassava Development in Nigeria: A Country Case Study Towards a Global Strategy for Cassava Development, Department of Agriculture Federal Ministry of Agriculture and Natural Resources Nigeria, http://www.fao.org/docrep/009/a0154e/a0154e05.htm (Accessed; 20-9-2013)

[10]. Donatus E.O (2012) Productivity and Efficiency of Nigeria Sea Ports : A Production Frontier Analysis, International Business Management $6(1): 41-46,2012$

[11]. FAO (2002), Partnership Formed to Improve Cassava, Staple Food for 600 Million people, http://www.fao.org/english/newsroom/news/2002/10541-en.html, Food and Agriculture Organization of the United Nations: Rome

[12]. FAO (2009)Food Outlook November 2009, Food and Agriculture Organization of the United Nations: Rome

[13]. FAOSTAT, database access dates as stated, In Tijaja., J (2009) The Impact of China's Demand on SMEs in Thai Cassava Value Chains, A PhD Dissertation , Development Policy and Practice, The Open University, UK

[14]. Garry., S.F (1980) Poverty, Inequality and Development, Cambridge, Cambridge University Press pp. 45-56

[15]. Hayes, D.(1977) Ray of Hope : The Transition to a Post-Petroleum World,A World Watch Institute Book, W.W. Norton and Company, London

[16]. Hilling D and Hoyle B. S (1970) Seaport and Development in Tropical Africa, Macmillian, London

[17]. Hurst E.E.M (1974) Transport Geography: Comments and Readings, Mac Grawhill Book Company

[18]. International Institute of Tropical Agriculture (2005) Additional Funding Program Description on Cassava Enterprise Development Project (CEDP)submitted to theUnited States Agency for International Development (USAID), Nigeria Mission and the Shell Petroleum Development Company (SPDC),Nigeria by the International Institute of Tropical Agriculture Ibadan, Nigeria March 21, 2005 
[19]. Johnson.,F (2011) Hints and Tips on Exporting Goods to Nigeria, Reliable Agricultural Procurement for Africa, Vellag, September , 2011, http://www.vellag.com/index.php/articles/hints-and-tips-on-exporting-goods-to-nigeria/(Accessed; 20-9-2013)

[20]. Money D.C. (1972) Introduction to Human Geography, Unuiversity Tutorial Press Ltd. London

[21]. Naira Land (2013)Procedures for Produce Export from Nigeria Chart, Export from Nigeria, http://www.nairaland.com/926677/export-nigeria

[22]. Nigeria Port Authority (1992) Focus on Calabar Port: Gateway to Nigeria's Eastern and North Ea stern Market, Nigeria

[23]. Nigeria Port Authority Annual Reports, 1982-1994)

[24]. Nigerian National Development Plan (1975-1980)

[25]. Nigeria News (2013) Obasanjo Exports Cassava Bread To Tanzania, http://news2.onlinenigeria. com/business/284469-obasanjoexports-cassava-bread-to-tanzania-pictured.html

[26]. OAE - Office of Agricultural Economics OAE (2006), A Study on the Export Po

[27]. Jidere C., M and Okeke .,F. I (2012) Determination of Agro-Ecological Zones in Nigeria Using Current Satellite Information ,Microsoft PowerPoint Presentation, University of Nigeria, Nsukka and Enugu Campuses, Nigeria

[28]. Obiozor C.C. et al (1989) Shipping Trade and Development in West and Central African Sub-region,Proceedings of an International Workshop, Nigerian Shippers Council, Business Graphics, Lagos

[29]. Oboli., H.D.N. (1978) A New Outline Geography of West Africa, African University Press, Lagos

[30]. Office of Agricultural Economics (2006), A Study on the Export Potential of Thai Cassava Chips Export to China after ThailandChina Free Trade Agreement (Translated from Thai), In Tijaja., J (2009) The Impact of China's Demand on SMEs in Thai Cassava Value Chains, A PhD Dissertation, Development Policy and Practice, The Open University, UK

[31]. Ogundana B (1972) Oscillating Seaport Location in Nigeria, Annals of the Association of American Geographers, vol. 62 , pp 110121

[32]. Ogundana B(1970) The Locational Factor in Changing Seaport Significance in Nigeria, Nigerian Geographical Journal, Vol. 14 pp71-88

[33]. Osagie., C. (2013) Nigeria to Export \$272m Worth of Cassava Chips to China, China Berry, Monday, January 21, 2013

[34]. Udo R.K., (1970) Geographical Regions of Nigeria, Heinemann, London

[35]. UNCOMTRADE. (2010). Trade Data [Electronic Version], In Tijaja., J (2009) The Impact of China's Demand on SMEs in Thai Cassava Value Chains, APhD Dissertation, Development Policy and Practice, The Open University, UK

[36]. University of Calabar (Undated) University of Calabar Students Handbook, Students Affairs Division, Canteur Press, Calabar Students Handbook

[37]. Ulman E.L and MeyeH.M (1954) Transport GeographyInJamesP.E and James C.L (1954) American Geography : Inventory and Prospects, Syracuse University, Syracuse

[38]. Vessia, A. (2007), Cassava: the Food of the Poor for Future Food Security, In Tijaja., J.(2009) The Impact of China's Demand on SMEs in Thai Cassava Value Chains, APhD Dissertation , Development Policy and Practice, The Open University, UK

[39]. TESCO-KOZIT Consulting Engineers (Nig.) Ltd (1972) Survey and Development Plan ForCalabar , Nigeria , Ministry of Town Planning, TESCO-KOZIT Consulting Engineers (Nig.) Ltd

[40]. Tijaja., J (2009) The Impact of China's Demand on SMEs in Thai Cassava Value Chains, A PhD Dissertation , Development Policy and Practice, The Open University, UKTodaro M.P. and Smith S.C. (2004) Economic Development, Eight Edition , Pearson Education, Singapore 